Luka Borović ${ }^{1}$

Katedra za psihologiju,

Filozofski fakultet Pale,

Univerzitet u Istočnom Sarajevu

Istočno Sarajevo, Republika Srpska, Bosna i Hercegovina

\section{Jelena Marković}

Srednja škola "Sveti Sava",

Loznica, Srbija
UDK 159.942:159.923.3

Originalni naučni rad

https://doi.org/10.46630/gpsi.18.2021.03

\title{
UNUTRAŠNJI RADNI MODELI AFEKTIVNE VEZANOSTI KAO PREDIKTORI MRAČNE TRIJADE
}

\begin{abstract}
Apstrakt
Osnovni cilj ovog istraživanja bilo je ispitati da li unutrašnji radni modeli sebe i značajnih drugih predstavljaju značajne prediktore osobina ličnosti mračne trijade. Pojam unutrašnjeg radnog modela je u okviru teorije afektivne vezanosti ona ključna spona koja povezuje prošlo iskustvo sa sadašnjim obrascima ponašanja, koje održavaju disfunkcionalna kognitivna uvjerenja nastala na osnovu generalizacija nepovoljnih iskustava. Mračna trijada se sastoji od osobina psihopatije, narcizma i makijavelizma. Korišćen je Upitnik za procjenu porodične afektivne vezanosti i Kratki upitnik mračne trijade. Uzorak istraživanja se sastojao od $N=123$, uz prosječnu starost ispitanika $M=30.41, S D=$ 9.06. Muškarci su činili 43\% uzorka. Sprovedene regresione analize pokazuju da je predikcioni model koji obuhvata dimenzije anksioznosti i izbjegavanja statistički značajan prediktor makijavelizma, $F(2,120)=6.26, p=.003, R^{2}=.09$, tj. predviđa $9 \%$ varijanse ove varijable, te psihopatije, $F(2,120)=8.98, p<.001, R^{2}=.13$, tj. predviđaju $13 \%$ varijanse ove varijable, ali ne i narcizma, $F(2,120)=0.24, p=.79, R^{2}=.01$, gdje je svega $1 \%$ varijanse previđeno regresionim modelom. Dimenzija izbjegavanje je statistički značajan i pozitivan prediktor psihopatije $(\beta=.29, p=.003)$, a dimenzija anksioznost statistički značajan i pozitivan prediktor makijavelizma $(\beta=.26, p=.004)$ i psihopatije $(\beta=.22, p=.025)$. Rezultati istraživanja sugerišu da u osnovi ove dvije osobine ličnosti leži doživljaj sebe kao neadekvatne osobe i svijeta kao neprijateljskog mjesta, u kome će druge osobe težiti da nam naškode ako budemo otvoreni prema njima. Manipulaciju i emocionalnu neosjetljivost psihopata i makijavelista treba tumačiti u ključu potrebe da se nađe kompromis prema ovim uvjerenjima. Sa druge strane, narcizam nije korelirao značajno sa radnim modelima, moguće usljed niskog stepena uvida jer je osoba investirana u odražavanje grandioznog selfa.
\end{abstract}

Ključne riječi: afektivna vezanost, radni modeli, mračna trijada

\footnotetext{
${ }^{1}$ luka.borovic@ffuis.edu.ba

Citirati rad na sledeći način: Borović, L. i Marković, J. (2021). Unutrašnji radni modeli afektivne vezanosti kao prediktori mračne trijade. Godišnjak za psihologiju, 18, 41-58. https://doi.org/10.46630/ gpsi.18.2021.03
} 


\section{Uvod}

\section{Unutrašnji radni modeli}

Iako je psihologija već od svojih najranijih dana prepoznala ogroman značaj porodičnih, naročito ranih iskustava po kasniji razvoj ličnosti i oblike ponašanja koje ispoljavamo u odraslom dobu (možda najbolje predočeno u čuvenoj Frojdovoj maksimi „Dijete je otac čovjeka "), pitanje objašnjenja konkretnih mehanizama putem kojih porodična a naročito rana iskustva vrši uticaj na naš kasniji život je ostalo daleko složenije i u velikoj mjeri neriješeno. Dok je npr. bihevioristička paradigma nastojala da objasni ovaj uticaj ranog iskustva putem sticanja navika i asocijativnih veza u procesu učenja, negirajući značaj viših kognitivnih aktivnosti i jezika, teorija afektivne vezanosti, kao jedna od najopsežnijih teorija ljudskog emocionalnog razvoja, nastojala da objasni ovaj uticaj kroz pojmove očekivanja, uvjerenja, vjerovanja, nesvjesnih šema međuljudskih odnosa i sebe (Jerković i Zotović, 2010). Drugačije rečeno, na osnovu intenziteta ranih emocionalnih iskustava djeteta i specifičnosti dječjeg intelekta i doživljaja svijeta, nastaju rana uvjerenja o sebi i drugima, koja kroz ostatak života teže da se održe selektivnim filtriranjem i interpretacijom iskustva tako da sve što doživljavamo potvrdi ove naša osnovne pretpostavke, kojih ne moramo biti u potpunosti svjesni (npr. „Drugima se ne može vjerovati“‘) (Mikulincer, 1995).

Prilikom određivanja značaja i dalekosežnosti posljedica ranog iskustva ne smijemo zanemariti specifičnosti dječjeg doživljaja svijeta i intelektualnog funkcionisanja. Za malo dijete, svijet je ogromno i prijeteće mjesto, spram koga je ono relativno nemoćno, te mu je stoga neophodna utjeha u vidu moćne, idealizovane i zaštitničke roditeljske figure - baze sigurnosti (Bowlby, 1982). Stoga poruke i postupci roditeljske figure imaju ogroman značaj u djetetovim očima i postaju osnova putem koje se donose dalekosežni zaključci o prirodi svijeta, međuljudskih odnosa i intimnosti, ali i sopstvene vrijednosti i kapaciteta. Djetetovo nezrelo i magijsko mišljenje često dovodi do pogrešne percepcije postupaka i situacija, njihovog doživljavanja kao u većoj mjeri prijetećih i emocionalno intenzivnih nego što to zaista jesu, te pretjerane generalizacije zaključaka na sve ostale ljude i život uopšte (tako npr. dijete na osnovu jednog traumatičnog iskustva separacije od majke u senzitivnom periodu može donijeti zaključak o sopstvenoj bezvrijednosti ili o prirodi svijeta kao opasnost mjesta) (Jerković i Zotović, 2010). Upravo ovakva uvjerenja i kognitivne šeme $u$ odraslom dobu leže $u$ korijenu velikog broja maladaptivnih ponašanja i patoloških ispoljavanja, koja se uporno ponavljaju i pored toga što ih osoba često doživljava kao neprijatne, disfunkcionalne i poražavajuće. U osnovi ponavljanja je nemogućnost da se ovi rani zaključci osvijeste, preispitaju i testiraju spram realnosti, te donesu nove i adekvatnije odluke u svjetlu odraslih kapaciteta osobe. Ova kognitivna uvjerenja formiraju prototipnu sliku intimnih odnosa i svoje vrijednosti u istima, a koje se označavaju nazivom unutrašnjih radnih modela, pri čemu se pod terminom anksioznost misli na negativni radni model sebe, a izbjegavanje na negativni radni model značajnih drugih, odnosno procjenu drugih kao nepouzdanih, beskorisnih, ugrožavajućih, itd. (Stefanović-Stanojević, 2011). 
Kao što je već istaknuto, pojam radnog modela vuče korijene iz teorije afektivne vezanosti Džona Bolbija (Bowlby, 1982). Teorija je nastala kao pokušaj da se objasni priroda i razvoj emocionalne vezanosti djeteta za druge ljude, što je Bolbi (Bowlby, 1982) posmatrao kao proces koji ne samo da je urođen, već ima i izuzetan evolutivni značaj u smislu preživljavanja relativno nemoćnog djeteta u potencijalno opasnoj sredini. Prva iskustva djeteta oblikuju njegove stavove, uvjerenja, mišljenja kao o sebi tako i o svijetu uopšte. Tačnije dijete uči kakva je struktura međuljudskih odnosa i šta od njih može očekivati (Jerković i Zotović, 2010). Kasnije je teorija afektivne vezanosti modifikovana na dva ključna načina: 1) prepoznavanje individualnih varijacija u kvalitetu afektivne vezanosti, koji se može kretati od sigurnog do nesigurnog, inspirisano radovima Meri Ejnsvort (Ainsworth et al., 2015) pokušaji objašnjenja ispoljavanja afektivne vezanosti na kasnijim uzrastima i kontinuiteta $\mathrm{u}$ našim emocionalnim iskustvima, te ophođenju prema sebi i značajnim drugima (Stefanović-Stanojević, 2011).

\section{Osobine mračne trijade}

Pojam „mračne trijade“ (eng. dark triad) obuhvata tri međusobno povezane, ali ipak distinktivne osobine ličnosti: makijavelizam, narcizam i psihopatiju (Paulhus \& Williams, 2002). Ove tri osobine ličnosti se često javljaju zajedno i njihova izražena dominacija u strukturi ličnosti može dovesti do poteškoća u interpersonalnom funkcionisanju, sklonosti ka različitim oblicima antisocijalnog ponašanja (poput manipulacije, eksploatacije ili otvorene agresije), specifične interpretacije iskustva i socijalnih situacija (u smislu emocionalne neosjetljivosti, ignorisanja prava i emocija drugih zarad lične koristi i održavanja grandioznog selfa itd.) (Wai \& Tilioupoulos, 2012).

Narcizam i psihopatija se smatraju subkliničkim varijantama istoimenih poremećaja ličnosti koji su obuhvaćeni dijagnostičkim kriterijumima Međunarodne klasifikacije bolesti (ICD-11; World Health Organisation, 2018), u kojima osobe ispoljavaju iste ključne crte ličnosti i ponašanja, ali ne do te mjere i sa tolikim intenzitetom da bi postigli nivo dijagnoze poremećaja ličnosti (Krumenacker, 2019). Kao osnovnu odliku narcizma možemo okarakterisati raskorak odnosno rascijep između grandioznog selfa, unutar koga osoba doživljava sebe kao savršenu, nepogrešivu, najuspješnijuod svih ljudi u svom okruženju, dominantnu, superiornu (Corry et al., 2008), generalno izuzetnu po svojim kvalitetima, itd., i sa druge strane realnog ili vulnerabilnog selfa koji je mučen osjećajem sumnje, inferiornosti, niskim samopoštovanjem, itd. (Holmes, 2003). Usljed ovoga narcistične osobe, iako na površini vjeruju u svoje grandiozne stavove, često prolaze kroz periode sumnje, psihičke patnje i pada samopoštovanja koje nastoje da preduprijede ekscesivnim traženjem pažnje, podrške i komplimenata drugih ljudi. Ovakvi ciljevi dovode do interpersonalnog stila ponašanja koji je obilježen eksploatacijom i zanemarivanjem drugih zarad sopstvenog ega i dobijanja pohvala i podrške po svaku cijenu. Bilo da se radi o kliničkim ili sublikičkim entitetima drugi ljudi narcisistične osobe vide kao socijalno odbojne (Leary et al., 1997) 
Sa druge strane, osnovnim obilježjem psihopatije i u njenom kliničkom i subkliničkom obliku se smatra nedostatak empatije prema drugima, ne toliko na kognitivnom (prepoznavanje emocija drugih) koliko na afektivnom nivou (proživljavanje emocija drugih) što je deficit koji uparen sa drugom ključnom odlikom psihopatije nedostakom kontrole svojih impulsa - dovodi do „eksplozivnih“ reakcija i ponašanja u vidu acting outa, agresivnog ponašanja, ulaženja u probleme sa zakonom itd. (Wai \& Tilioupoulos, 2012). Nemogućnost adaptacije na društvene norme i stalni sukobi sa drugima i zakonom su do te mjere izraženi u kliničkoj psihopatiji da se u modernim klasifikacijama ovaj poremećaj imenuje kao ,antisocijalna ličnost“" (Marić, 2006). Tako je u okviru Dijagnostičkog i statističkog priručnika mentalnih poremećaja (The Diagnostic and Statistical Manual of Mental Disorders, 5th ed.; DSM-V; American Psychiatric Association, 2013) ovaj poremećaj ličnosti prvenstveno definisan kroz različite oblike ponašanja koje osoba ispoljava, pri čemu je naglasak stavljen na nemogućnost konformiranja socijalnim normama, impulsivnost, sklonost laganju i manipulaciji drugima, iritabilnost i agresivnost, neobaziranje na sopstvenu dobrobit i dobrobit drugih, nedostatak kajanja i griže savjesti povodom svojih postupaka, te neodgovornost koja dovodi do značajnih teškoća u održavanju radnih odnosa i trajnih interpersonalnih bliskih odnosa. Psihopatija se i u svom kliničkom i subkliničkom obliku posmatra kao najproblematičnija osobina u okviru mračne trijade (Rauthmann, 2012)

Makijavelizam, kao treći član mračne trijade, je imenovan od strane Christia i Geisa (Christie \& Geis, 1970, prema Mrđa, 2017), autora koji su pokušali da naprave instrument za mjerenje ove osobine ličnosti koristeći fraze i maksime koje srećemo u čuvenom djelu ,Vladalac“ italijanskog pisca Nikola Makijavelija. U ovom dijelu, iako mnogi istoričari književnosti i dalje vode rasprave da li je napisano sa satiričnom namjerom ili ne, Makijaveli iznosi niz savjeta o onim kvalitetima koji po njemu čine ,savršenog“" vladara, a knjiga je do te mjere postala uticajna da su neke njene fraze - poput „cilj opravdava sredstvo“ ili „,bolje je da te se plaše nego da te vole“ - ušle u kolokvijalni jezik. Suština makijavelizma kao osobine ličnosti ogleda se u emocionalnoj neosjetljivosti prema drugima, sklonosti hladnokrvnoj manipulaciji kako bi se ostvarili željeni ciljevi, neobaziranju na društvene i klasične moralne norme, te generalno ciničnim stavovima i odnosom prema životu (Jakobwitz \& Egan, 2006; Paulhus \& Williams, 2002). Osobe kod kojih je izražena crta makijavelizma duboko veruju da je manipulacija ključ uspješnog života (Jones \& Paulhus, 2009)

Jedno pitanje koje se postavlja jeste ono o međusobnim odnosima tri člana mračne trijade, tj. ovim osobinama koje imaju zajedničkih tačaka, ali i fundamentalnih razloga. Članak Paulhusa i Williamsa (2002) je ključan u ovome smislu jer je među prvima empirijski dokazao da ove tri osobine imaju različite korelate. Ovi autori su takođe jasno razgraničili sadržaj sve tri osobine ličnosti, naglašavajući da je osnovna karakteristika narcizma pretjerano pozitivan ili grandiozan doživljaj selfa, koji ne srećemo kod druga dva člana trijade (Jacoby, 1991). Ovo su Paulhus i Williams na vrlo ubjedljiv način ilustrovali kroz pozitivnu korelaciju narcizma sa diskrepancom između samoprocjenjene inteligencije i objektivnih rezultata na testu inteligencije, a koja nije bila prisutna kod makijavelizma i psihopatije. Takođe, 
značajno je istaći da su ciljevi narcisoidnog ponašanja drugačiji u odnosu na ono makijavelističkih i psihopatskih ličnosti. Narcisoidne osobe prvenstveno teže pohvalama i pažnji od strane drugih ljudi, tj. jačanju grandioznog selfa kroz socijalna potkrepljenja, dok su druge dvije grupe usmjerene na konkretnu materijalnu dobit.

Osnovnu razliku između makijavelizma i psihopatije je nešto teže odrediti. Obje crte ličnosti uključuju nedostatak empatije, manipulativno ponašanje i poricanje prava drugih zarad ličnog interesa (Krumenacker, 2019). Međutim, impulsivnost i emocionalna ,eksplozivnost“" koje su pristune kod psihopatije su odsutne kod makijavelističkih ličnosti. Drugačije rečeno, makijavelisti ispoljavaju značajno veći stepen emocionalne stabilnosti i njihove antisocijalne reakcije nisu rezultat neprilagođenog emocionalnog odgovora, već pažljivog planiranja i manipulacije čiji su konačni cilj isključivo soptvena korist (Paulhus \& Williams, 2002).

\section{Prethodna empirijska istraživanja}

Na koji način prošlo iskustvo iz djetinjstva utiče na naše ponašanje u sadašnjim odnosima? Zašto nam se u toliko situacija i odnosa ponavljaju iste greške, misli, oblici ponašanja, kao preuzeti iz „scenarija“ koje smo napisali još u ranim danima našeg života? Teorija afektivne vezanosti nudi odgovor u vidu radnih modela kao one ključne spone između prošlosti i sadašnjosti ili, preciznije rečeno, trajnih kognitivnih reprezentacija prethodnih iskustava koje osoba i sada koristi kako bi interpretirala situacije i poruke drugih (Mikulincer, 1995). Radni modeli prožimaju našu percepciju, kogniciju, ponašanje, emocije, itd., tj. njihov uticaj je obuhvatan, ali implicitan, tj. osoba ih najčešće nije svjesna u punoj mjeri (Jerković i Zotović, 2010). Disfunkcionalna uvjerenja o sebi ili drugima - npr. „Ja ne zaslužujem da me drugi vole jer ne vrijedim“ ili „Svijet je opasno mijesto i ljudi će ti naškoditi ako im daš priliku“ - leže u osnovi nesigurnih obrazaca afektivne vezanosti, poput preokupiranog ili izbjegavajućeg (Mikulincer, 1995). Ako shvatimo radni model kao prototipnu sliku intimnog odnosa u skladu sa kojom se procjenjuju svi aktuelni odnosi osobe i postupa, jasno je da mnoga disfunkcionalna kognitivna uvjerenja leže u osnovi iskrivljenih slika prototipnog odnosa - koji može biti nerecipročan, duboko ambivalentan, ili pak otvoreno hostilan i manipulativan.

Iako su se mnoga istraživanja fokusirala na posljedice osobina ličnosti mračne trijade na funkcionisanje $\mathrm{u}$ romantičnim odnosima, u porodici, u psihoterapijskom miljeu pa čak i na radnom mjestu, daleko je manje studija koje su pokušavale da utvrde potencijalne faktore koji su doveli do formiranja ovih osobina ličnosti, te kroz koja kognitivna uvjerenja se ona održavaju i utiču na interpretaciju iskustva osobe (Krumenacker, 2019). Stoga smo se u ovom radu fokusirali na povezanost mračne trijade sa unutrašnjim radnim modelima, tj. setom kognitivnih uvjerenja o sebi, bliskim osobama i međuljudskim odnosima generalno, a koja nastaju kroz rana iskustva, poruke i modele kojima je osoba bila izložena u djetinjstvu (Jerković i Zotović, 2010).

Stoga se nameće pitanje odnosa mračne trijade $\mathrm{i}$ ovih predstava o intimnim odnosima, sebi i drugima, tj. savim je opravdano pretpostaviti da su nepovoljna rana 
iskustva formirala ovakvu strukturu ličnosti, koja se održava kroz disfunkcionalne kognitivne reprezentacije i konzistentne greške u tumačenju svojih emocija, prava i mišljenja drugih, socijalne situacije, itd. Čak i kada se osoba iskrivljene slike o intimnosti susretne sa relativno pozitivnim iskustvima, ona će ih selektivno tumačiti i vrednovati kako bi održala i validirala svoj unutrašnji model. Kao što je već istaknuto, postoji osjetan nedostatak empirijskih istraživanja na ovu temu.

Osnovni problem ovog istraživanja odnosi se na prediktorsku ulogu unutrašnjih radnih modela značajnih drugih i sebe, kao ključnih reprezentacija intimnih odnosa koje se formiraju u ranom djetinjstvu i utiču na našu percepciju i ponašanje u socijalnim odnosima, u predviđanju stepena izraženosti osobina ličnosti „mračne trijade“ - subkliničkog narcizma, psihopatije i makijavelizma - koje se često pojavljuju zajedno i predisponiraju osobu ka asocijalnim i antisocijalnim oblicima ponašanja, a u osnovi im leži deficit empatije. U tom smislu cilj istraživanja je potvrditi hipotezu o povezanosti ova dva konstrukta, sa osnovnom pretpostavkom da u korijenu ova tri maladaptivna oblika ponašanja leže nepovoljna rana iskustva u primarnoj porodici koja su dovela do iskrivljenih uvjerenja u vezi sa svijetom, sobom, drugima i međuljudskim odnosima uopšteno, što je dalje dovelo do deficita u regulaciji emocija i percepciji socijalnih situacija.

U ovom istraživanju afektivna vezanost je mjerena na osnovu trenutnih obrazaca ponašanja u odnosima sa primarnom porodicom, a za koje se pretpostavlja da odražavaju kvalitet ranih iskustava i odnosa u porodici na osnovu kojih su se formirali prototipi budućih odnosa - radni modeli sebe i drugog. Veliki broj studija pokazuje stabilnost obrazaca afektivne vezanosti kroz cjelokupni životni vijek, prvenstveno usljed tedencije da se nova iskustva i odnosi tumače u smislu ranijih odnosa, te pronalaženja partnera i relacija koji potvrđuju naša bazična uvjerenja (Stefanović-Stanojević, 2011). Ipak, to ne znači da promjene afektivne vezanosti i radnih modela (kako u smjeru sigurnosti, tako i povećane nesigurnosti i ambivalencije) nisu moguće, tj. vjerovatno postoji jedna značajna manjina ispitanika čiji su obrasci ponašanja promjenjeni u odnosu na rana iskustva, a pod uticajem kasnijih. Nažalost, ovo pitanje nije dublje preispitano u okviru ovoga istraživanja, te su stoga i rezultati interpretirani u svjetlu ovog ograničenja.

Značajan problem koji se javlja prilikom pregleda istraživanja o relacijama afektivne vezanosti i mračne trijade jeste različit način konceptualizacije afektivne vezanosti u onim studijama koje se uistinu bave ovom temom. Naime, afektivnu vezanost je moguće posmatrati na nivou radnih modela kao kontinuirane dimenzije doživljaja sebe i drugih - koja varira od ekstremno pozitivnih do ekstremno negativnih statova - ali i kategorijski, tj. kroz pripadnost nekim od identifikovanih obrazaca afektivne vezanosti. Tako npr. Krumenacker (2019) u svom istraživanju utvrđuje pozitivne i značajne korelacije između dimenzija negativnog radnog modela sebe i značajnog drugog sa sve tri osobine ličnosti mračne trijade, što objašnjava nepovoljnim iskustvima za vrijeme odrastanja u primarnoj porodici koja su internalizovana u vidu kognitivnih reprezentacija i interpersonalnog stila ponašanja koji ih odslikava. Od istraživanja sprovedenim na našim prostorima, neophodno je istaći rad Mrđe (2017) koji je afektivnu vezanost tretirao kao kategorijsku varijablu. U ovom 
radu, ispitanici koji su pripadali nekom od nesigurnih obrazaca afektivne vezanosti, tj. preokupiranom ili izbjegavajućem, su imali veće skorove na osobinama ličnosti mračne trijade u odnosu na one koji su pripadali sigurnom obrascu vezanosti.

Istraživanje Jonasona, i saradnika (Jonason et al., 2014) je još jedna studija u kojoj se nastojala pokazati povezanost između kvaliteta roditeljske njege, pripadnosti nekom od obrazaca afektivne vezanosti, te osobina ličnosti mračne trijade. Ova studija je specifična po tome što su kvalitet njege majke i oca odvojeno ocjenjivani, te po tome što su osobine ličnosti mračne trijade bile razložene na njihove uže facete. Tako je npr. narcizam podijeljen na njegove pozitivnije kvalitete, kao što je sklonost ka preuzmanju vođstva, te negativnije, poput grandioznosti i sklonosti ka eksploataciji drugih, dok je psihopatija razložena na primarnu i sekundarnu. Pod primarnom psihopatijom se misli na nedostatak empatije prema drugima koji se posmatra kao ključni deficit ove osobine iz koje proističu sve druge karakteristike i obrasci ponašanja, a pod sekundarnom psihopatijom na sklonost ka antisocijalnim oblicima ponašanja i nemogućnost da se konformira društvenim normama i očekivanjima. Rezultati istraživanja su pokazali da sigurna afektivna vezanost negativan prediktor praktično svih aspekata osobina mračne trijade, dok je bojažljiva vezanost pozitivan prediktor makijavelizma. Neophodno je napomenuti da je kvalitet majčine brige bio i indirektan prediktor mračne trijade kroz svoj odnos sa afektivnom vezanošću, ali i direktan negativan prediktor patoloških aspekata narcizma. Ovo nas upućuje na to da uticaj roditeljskog ponašanja i vaspitanja na ličnost osobe može biti dvojak: kroz direktno modeliranje različitih oblika ponašanja (npr. eksploatacija drugih ili grandioznost u pogledu sopstvene vrijednosti), ali i indirektan, kroz usvajanje osnovnih uvjerenja o svijetu, sebi i drugima, tj. radnih modela.

U studiji Brewera i saradnika (Brewer et al., 2018) ispitani su odnosi između mračne trijade i radnih modela u kontekstu partnerskih odnosa, koji su najznačajniji i emocionalno najintenzivniji odnosi osobe u ranom odraslom dobu. U datoj studiji, psihopatija je bila značajan pozitivan prediktor negativnog radnog modela sebe/ anksioznosti, a narcizam značajan i negativan prediktor. Sa druge strane, psihopatija i makijavelizam su bili statistički značajni i pozitivni prediktori negativnog radnog modela drugih/izbjegavanja.

Moguće je uočiti određene trendove i ograničenja svih nabrojanih empirijskih studija. Kao prvo, praktično svaka studija je podrazumijevala retroaktivne iskaze i prisjećanja iskustava o odnosima i kvalitetu vezanosti u njihovim primarnim porodicama, pri čemu su često zanemareni uticaji ostalih (van-porodičnih) afektivnih iskustava koja su mogla promijeniti kvalitet afektivne vezanosti do odraslog doba (poput odnosa sa prijateljima, mentorskim figurama, partnerima, itd.). Ono što je takođe značajno jeste da sve nabrojane studije osim poslednje, Brewera i saradnika, postuliraju obrasce afektivne vezanosti i radne modele kao nezavisnu varijablu, a osobine ličnosti mračne trijade kao zavisnu varijablu. Varijable su tako koncipirane i u ovom istraživanju, uzimajući u obzir da osoba postepeno gradi osobine ličnosti i obrasce ponašanja kroz iskustva u ranim odnosima, reakcije drugih na njene postupke i "pravila" intimnih odnosa na koje je navikla. Iako osobine ličnosti jesu i pod uticajem temperamenta i naslijeđa osobe, njihovo formiranje i ispoljavanje je 
takođe rezultat i iskustava u socijalnoj sredini, naročito ranih i porodičnih koja postaju "prototip" budućih iskustava. Studija Brewera i saradnika (Brewer et al., 2018) je postavila osobine ličnosti mračne trijade kao nezavisne varijable spram afektivne vezanosti u partnerskim odnosima jer na kvalitet konkretnog partnerskog odnosa utiču i raniji obrasci afektivne vezanosti i osobine ličnosti osobe, tj. osoba je već u velikoj mjeri formirana i novi socijalni odnosi daleko teže mijenjaju njenu osnovnu strukturu ličnosti.

$\mathrm{Na}$ osnovu rezultata ovog i drugih prikazanih istraživanja, formulisane su sledeće hipoteze: H1. Anksioznost je statistički značajan i pozitivan prediktor psihopatije., H2. Anksioznost je statistički značajan i negativan prediktor narcizma., H3. Izbjegavanje je statistički značajan i pozitivan prediktor psihopatije., H4. Izbjegavanje je statistički značajan i pozitivan prediktor makijavelizma.

\section{Metod}

\section{Uzorak i procedura}

Uzorak ovog istraživanja sastojao se od ukupno 123 ispitanika, prikupljenih putem anonimne onlajn ankete na platformi „Google Forms“ u periodu juna i jula 2020. godine, prvenstveno na području sarajevsko-romanijske regije. Usljed situacije uzrokovane pandemijom koronavirusa, ispitivanje je obavljeno onlajn, a ne uživo.

Po svojim karakteristikama uzorak je polno uravnotežen, pri čemu ispitanice čine 56.93\% uzorka, a ispitanici $43.17 \%$ uzorka. Starost ispitanika se kreće između 20 i 63 godine, pri čemu prosječna starost iznosi $M=30.41$ godinu, a standardna devijacija $S D=9.06$, što znači da $66 \%$ ispitanika ima između 21 i 39 godina. Većina ispitanika nije trenutno u braku, njih $64.23 \%$, a njih $35.82 \%$ je trenutno u braku. Dva najbrojnija obrazovna profila su oni sa završenim fakultetom, koji čine $54.52 \%$ od ukupnog uzorka, te oni sa završenom srednjom školom, koji čine $38.22 \%$ od ukupnog broja ispitanika.

\section{Instrumenti istraživanja}

U istraživanju su korišćeni sledeći instrumenti: Upitnik za procjenjivanje porodične afektivne vezanosti autora Brenana, Clarka i Shavera (1998), te Kratki upitnik mračne trijade (Short Dark Triad - SD3) autora Jonesa i Paulhusa (2014).

Upitnik za procjenjivanje porodične afektivne vezanosti (Experiences in Close Relationships; Brennan et al., 1998; za domaću adaptaciju vidjeti Kamenov i Jelić, 2003) sastoji se od ukupno 18 tvrdnji, a sa kojima ispitanici izražavaju svoje (ne) slaganje na brojčanoj skali od 1 do 7 , pri čemu 1 označava „uopšte se ne slažem“, a 7 ,u potpunosti se slažem“. Skala se sastoji od dvije subskale, anksioznosti i izbjegavanja, koje obuhvataju po 9 stavki. Subskala anksioznost se odnosi na negativan radni model sebe, odnosno kognitivna uvjerenja i ponašanja koja se odnose na doživljaj sebe kao neadekvatnog, sumnju u to da ćemo uspjeti da obezbijedimo pažnju i podršku drugih i svjesnost o zavisnosti od istih, što dovodi do snažnog straha od 
usamljenosti i napuštanja. Sa druge strane, subskala izbjegavanje sa odnosi na negativni radni model značajnih drugih, odnosno na uvjerenje o drugima kao osobama kojima se ne možemo otvoriti, povjeriti, koji imaju zle namjere prema nama, kojima se ne može i ne smije vjerovati, što dovodi do distancirajućih, hladnih i odbacujućih oblika ponašanja. Pouzdanost subskala dobijena na uzorku ovog istraživanja, izražena putem alfa kronbah koeficijenta, iznosi $\alpha=.78$ za subskalu izbjegavanje, odnosno $\alpha=.76$ za subskalu anksioznosti.

Kratki upitnik mračne trijade (Short Dark Triad - SD3; Jones \& Paulhus, 2014; za srpsku adaptaciju vidjeti Dinić et al., 2018) sastoji se od ukupno 27 stavki, a ispitanici izražavaju svoje slaganje sa svakom od njih na skali od 1 do 5 , pri čemu 1 označava „nimalo se ne slažem“, a 5 „u potpunosti se slažem“. Skala obuhvata tri subskale: makijavalizam, narcizam i psihopatiju. Svaka od ove tri subskale obuhvata 9 stavki. Pouzdanost subskaladobijena na uzorku ovog istraživanja je takođe izračunata putem alfa kronbah koeficijenta: makijavelizam $=.74$, narcizam $=.65$, psihopatija $=.79$. Dakle, pouzdanost svih subskala je u okviru zadovoljavajućih ili prihvatljivih vrijednosti.

\section{Rezultati}

Prvi korak sprovedene obrade podataka bio je računanje osnovnih deskriptivnih vrijednosti svih skala i subskala koje obuhvataju. Budući da su svi konstrukti obuhvaćeni istraživanjem u određenoj mjeri patološki ili barem maladaptivni, od negativnih kognitivnih modela sosptvene vrijednosti i vrijednosti drugih do subkliničkih verzija obrazaca ponašanja karakterističnih za poremećaje ličnosti, implicitno očekivanje je da oni neće biti u većoj mjeri prisutni u uzorku koga su činili ispitanici iz opšte populacije. Rezultati sprovedenih testova dati su u Tabeli 1.

Tabela 1

Deskriptivne vrijednosti i testovi normalnosti distribucije korišćenih skala

\begin{tabular}{lrrrrrr}
\hline Skala & \multicolumn{1}{c}{ Min } & Max & \multicolumn{1}{l}{ M } & \multicolumn{1}{c}{$S D$} & \multicolumn{1}{c}{$S k$} & \multicolumn{1}{c}{$K u$} \\
\hline Afektivna vezanost & & & & & & \\
Anksioznost & 15.00 & 42.00 & 20.08 & 6.55 & 0.56 & -0.12 \\
Izbjegavanje & 9.00 & 37.00 & 24.36 & 6.47 & 0.61 & -0.24 \\
Mračna trijada & & & & & & \\
Makijavelizam & 9.00 & 45.00 & 30.72 & 6.63 & -0.57 & 0.71 \\
Narcizam & 11.00 & 45.00 & 25.46 & 5.78 & 0.17 & 0.77 \\
Psihopatija & 9.00 & 41.00 & 20.24 & 7.16 & 0.61 & -0.17 \\
\hline
\end{tabular}

Napomene. $M=$ aritmetička sredina; $S D=$ standardna devijacija; $S k=$ skjunes; $K u=$ kurtozis.

Na osnovu pregleda vrijednosti skjunisa i kurtozisa distribucije skorova datih u Tabeli 1, može se zaključiti da svi dobijeni rezultati imaju trend normalne distri- 
bucije te da je stoga opravdano primjeniti parametrijske statističke postupke poput Pirsonovog koficijenta korelacije i linearne regresije u daljoj obradu podataka.

Prije sprovođenja regresione analize, prvo su izračunati koeficienti korelacije između svih varijabli uključenih u istraživanje. Prema teoriji i rezultatima ranijih empirijskih istraživanja, osobine ličnosti mračne trijade bi trebale da umjereno koreliraju međusobno, budući da su im mnogi oblici ponašanja zajednički, prvenstveno stavljanje svojih potreba ispred prava i potreba drugih, te pokušaj da se one realizuju i na štetu drugih, bilo putem agresije, bilo putem suptilnije manipulacije. Korišćen je Pirsonov koeficijent korelacije.

\section{Tabela 2}

Koeficijenti korelacije varijabli istraživanja

\begin{tabular}{lccccc}
\hline & 1 & 2 & 3 & 4 & 5 \\
\hline 1. izbjegavanje & & $.21^{*}$ & .17 & -.05 & $.31^{* *}$ \\
2. anksioznost & & $.28^{* *}$ & .03 & $.25^{* *}$ \\
3. makijavelizam & & & $.29^{* *}$ & $.39^{* *}$ \\
4. narcizam & & & & $.52^{* *}$ \\
5. psihopatija & & & & \\
\hline
\end{tabular}

Napomena. $* p>.05 ; * * p>.01$

Kao što vidimo, sve tri dimenzije mračne trijade međusobno koreliraju statistički značajno, umjereno i pozitivno. Najviša je korelacija između narcizma i psihopatije, a najniža između makijavelizma i narcizma.

Sa druge strane, anksioznost korelira statistički značajno i pozitivno sa makijavelizmom i psihopatijom, a izbjegavanje sa psihopatijom, što upućuje na pogodnost podataka za sprovođenje linearne regresije.

U daljoj obradi podataka sprovedene su tri linearne regresije kako bi se utvrdilo da li su radni model sebe i značajnog drugog statistički značajni prediktori makijavelizma, narcizma i psihopatije. Hipoteze u pogledu očekivanih rezultata regresije su postavljene na osnovu teorijskih saznanja i sličnih empirijskih istraživanja na ovu temu. Rezultati prve sprovedene regresije dati su u Tabeli 3.

\section{Tabela 3}

Regresioni model radnih modela kao prediktora makijavelizma

\begin{tabular}{llccc}
\hline Model & Prediktori & $\beta$ & $t$ & $p$ \\
\hline$R=.31, R^{2}=.09$, & Izbjegavanje & .12 & 1.35 & .181 \\
$\begin{array}{l}F(2,120)=6.26, \\
p=.003\end{array}$ & Anksioznost & .26 & 2.92 & .004 \\
\hline
\end{tabular}

Napomena. $\beta=$ standardizovani regresioni koeficijent; $t=$ vrednost $t$ statistika. 
Rezultati sprovedene regresije pokazuju da je model u cjelini statistički značajan i da predviđa ukupno $9 \%$ varijanse zavisne varijable tj. makijavelizma. Kao pojedinačni značajan prediktor javlja se dimenzija anksioznosti, koja je pozitivan prediktor makijavelizma $(\beta=.26, p=.004)$. Ovo je donekle iznenađujući rezultat ako uzmemo u obzir da svjesni stav osoba izraženog makijavelizma, usmjeren na manipulaciju drugima, ne sugeriše ovakav emocionalni odnos prema sebi, odnosno nedostatak osjećaja lične vrijednosti. Moguće je da se ciničan stav i manipulacija makijavelista javljaju kao odbrana od ovog bazičnog osjećaja manje vrijednosti i straha da njihove potrebe neće biti zadovoljene ako otvoreno traže intimnost i podršku od drugih. Četvrta hipoteza nije potvrđena.

\section{Tabela 4}

Regresioni model radnih modela kao prediktora narcizma

\begin{tabular}{llccc}
\hline Model & Prediktori & $\beta$ & $t$ & $p$ \\
\hline$R=.06, R^{2}=.01$, & Izbjegavanje & -.05 & -0.61 & .541 \\
$F(2,120)=0.24$, & Anksioznost & .04 & 0.43 & .666 \\
$p=.789$ & &
\end{tabular}

Napomena. $\beta=$ standardizovani regresioni koeficijent; $t=$ vrednost $\mathrm{t}$ statistika.

Kao što vidimo u goreprikazanoj tabeli, model obuhvata svega $1 \%$ varijanse narcizma, te u cjelini nije statistički značajan. Dakle, ni dimenzija anksioznosti ni dimenzija izbjegavanja se nisu pokazale kao statistički značajni prediktori narcizma, tj. druga hipoteza istraživanja nije potvrđena.

\section{Tabela 5}

Regresioni model radnih modela kao prediktora psihopatije

\begin{tabular}{llccc}
\hline Model & Prediktori & $\beta$ & $t$ & $p$ \\
\hline $\mathrm{R}=.36, \mathrm{R}^{2}=.13$, & Izbjegavanje & .29 & 3.03 & .003 \\
$\mathrm{~F}(2,120)=8.97$, & Anksioznost & .22 & 2.27 & .025 \\
$\mathrm{p}<.001$ & & & \\
\hline
\end{tabular}

Napomena. $\beta=$ standardizovani regresioni koeficijent; $t=$ vrednost $\mathrm{t}$ statistika.

Model je u cjelini statistički značajan i predviđa $13 \%$ varijanse psihopatije. Oba prediktora su bili značajni i pozitivni prediktori, tj. i izbjegavanje $(\beta=.29, p=.003) \mathrm{i}$ anksioznost $(\beta=.22, p=.025)$ Ovim su prva i treća hipoteza istraživanja potvrđene.

Ovakvi rezultati sugerišu da mnoge osobe kod kojih je ova osobina izražena imaju negativan model i sebe $i$ drugog. Ovako nepovoljna uvjerenja bi potencijalno mogla da objasne izrazito maladaptivne obrasce ponašanja osoba izražene psihopatije, odnosno ispoljavanje svojih agresivnih impulsa kroz nasilje ka drugima (čija se prava i vrijednost negiraju), ali nerijetko i prema samima sebi, bilo kroz dolaženje u sukob sa zakonom ili zloupotrebu supstanci (što upućuje na pokušaje da se održi cjelovitost i balans ličnosti koju muči unutrašnji osjećaj praznine, dosade i nedostat- 
ka lične vrijednosti).

\section{Diskusija i zaključak}

Sam konstrukt mračne trijade kao skupa tri međusobno povezane ali i distinktivne osobine ličnosti i stila ponašanja našao je primjenu u mnogim područjima psihologije, od proučavanja odnosa na radnom mjestu pa do kliničke psihologije i procesa savjetovanja/psihoterapije (Krumenacker, 2019). Ono što prepoznavanje i rad na ublažavanju ovih osobina ličnosti čini naročito korisnim u praktičnom radu jeste činjenica da se radi o subkliničkim verzijama psihopatoloških poremećaja (tj. kliničkog narcizma i psihopatije), odnosno maladaptvnim obrascima ponašanja i kognicija koji nikada ne dosežu nivo intenziteta neophodan za formalnu dijagnozu, iako osiromašuju i otežavaju život same osobine i njene sredine. Usljed ovoga, često se dešava da ovi obrasci ponašanja ostaju godinama neprepoznati i neimenovani, što značajno umanjuje mogućnost psihološke intervencije i pružanja pomoći, naročito ako uzmemo u obzir da ovaj profil klijenata ima nizak stepen uvida (budući da patologije prožima čitavu ličnost) i da izvore svojih teškoća tipično nalaze u drugima (Marić, 2006). Međutim, drugi podjednako značajan aspekt jeste informisanje opšte populacije o tipičnim obrascima ponašanja osoba kod kojih je neka od osobine ličnosti mračne trijade izražena, kako bi se mogli lakše oduprijeti pokušajima manipulacije i prepoznati da se nalaze u patološkim odnosima.

Iako postoji dosta istraživanja na temu međusobnog odnosa tri osobine koje čine trijadu, odnosno po kojim aspektima se razlikuju, a po kojima su slični, te korelata ovih osobina i njihovih posljedica po interpersonalno funkcionisanje osobe, daleko je manje studija koje se bave uzrocima učvršćivanja ovih osobina ličnosti i obrazaca ponašanja, odnosno etiologijom mračne trijade. Wai i Tiliopoulos (2012) smatraju da je u osnovi sve tri osobine ličnosti zajednički deficit, i to afektivne empatije, tj. sposobnosti da nakon što razumijemo osjećanja drugih na kognitivnom planu imamo i doživljaj istih do određene mjere. Tri mračne osobine ličnosti bi bile obrazac ponašanja izgrađen oko ovoga osnovnog defekta, bilo u smjeru grandioznog selfa (narcizam), impulsivnosti i agresije prema drugima (psihopatija) ili hladnokvrne manipulacije drugima (makijavelizam). Ipak, ovim pristupom se zanemaruje uticaj radnih modela kao prototipnih slika intimnih odnosa, sopstvene i tuđe vrijednosti i ponašnja u istina, kao i uslove odrastanja osobe kroz koje su one formirane. Cilj ovoga istraživanja jeste da pokuša da utvrdi postojanje povezanosti između osobina ličnosti mračne trijade sa jedne strane, te radnih modela sebe $i$ značajnih drugih kao one ključne spone između sadašnjih uvjerenja i prošlih iskustava, a o kojima govori uticajna teorija afektivne vezanosti.

Kroz rana iskustva, dijete formira uvjerenja o sebi, svijetu, značajnim drugima i načinu na koji funkcionišu međuljudski odnosi (Stefanović-Stanojević, 2011). Ova iskustva i na osnovu njih doneseni zaključci se generalizuju do nivoa unutrašnjeg radnog modela, kao stabilne kognitivne reprezentacije koja utiče na našu percepciju, interpretaciju i ponašanje. Kognitivistički orijentisane psihoterapijske škole korijene mnogih poremećaja ličnosti i njihovih subkliničkih varijacija nalaze upravo u kognitivnim uvjerenjima ovog tipa, poput oprečnih uvjerenja o sopstvenoj vrijedno- 
sti i bezvrijednosti koji su u osnovi dinamike narcizma, ili sistematskog negiranja prava i emocija drugih koje srećemo kod psihopata (Marić, 2006). Ova uvjerenja se učvršćuju na osnovu nepovoljnih ranih odnosa u porodici, koji mogu biti obilježeni emocionalnom hladnoćom, „duplim porukama“, narcisoidnim ili agresivnim modelima ponašanja, itd. Stoga je proučavanje radnih modela i osobina ličnosti mračne trijade način da pronađemo onu sponu koja povezuje ranija iskustva osobe sa njenim maladaptivnim oblicima ponašanja koje ispoljava u sadašnjosti.

Uzorak istraživanja sastojao se od ukupno 123 ispitanika, koji su anketirani putem anonimne onlajn ankete na platformi „Google Forms“ usljed pandemije koronavirusa. Ispitanici nisu imali prethodnu istoriju mentalnih bolesti ili traženja psihološke stručne pomoći, što je značajno ako uzmemo u obzir da su osobine mračne trijade prisutne i u ,normalnoj“ tj. prosječnoj populaciji, kao subliničke varijante ozbiljnijih oblika patologije ličnosti. Dalje, može se reći da je anonimna priroda istraživanja potencijalno čak i doprinijela iskrenosti odgovora ispitanika, budući da mnogi elementi ovih osobina obuhvataju nepoželjna i antisocijalna ponašanja i razmišljanja o drugima.

Sprovedene regresione analize pokazuju da je prediktivni model koji sačinjavaju izbjegavanje i anksioznost, odnosno negativni radni model drugih i sebe, značajan u predviđanju makijavelizma i psihopatije, te obuhvata $9 \%$ i 13\% varijanse ove dvije varijable. Međutim, jedini statistički značajan pojedinačan prediktor makijevalizma je bila dimenzija anksioznost, dok su i anksioznost i izbjegavanje bili statistički značajni i pozitivni prediktori psihopatije. Sa druge strane, model u cjelini nije bio statistički značajan prediktor narcizma. Ovakvi rezultati idu u prilog potvrđivanja prve i treće hipoteze istraživanja, a protiv druge i četvrte.

Ovakvi rezultati daju zanimljive implikacije po međuodnose obuhvaćenih varijabli i svakako potvrđuju osnovnu pretpostavku ovog istraživanja, prema kojoj kognitivne reprezentacije ranih iskustava i zaključci donešeni na osnovu istih (radni modeli) doprinose formiranju određenih obrazaca ličnosti i njihovom ispoljavanju kroz različite oblike ponašanja i u odraslom dobu. U slučaju osobina mračne trijade, koje podrazuumijevaju maladaptivne oblike ponašanja i kratkoročne strategije usmjerene na trenutnu korist i po cijenu dugoročne štete i uništavanja interpersonalnih odnosa, opravdano je pretpostaviti da u korijenu leže nepovoljna rana iskustva koja su dovela do ekstremnih zaključaka o prirodi svijeta sebe i drugih. Ono što je zanimljivo jeste da psihopatiju značajno predviđaju i negativni radni model sebe i drugih, što upućuje na duboko negativnu sliku svijeta i sebe, tj. drugi se opažaju kao nepouzdani, neprijateljski nastrojeni, a sama osoba kao manje vrijedna i nesposobna da na direktan način dobije ono što želi. U svijetlu ovako negativne interpretacije iskustva emocionalni izlivi, teškoća sa kontrolom impulsa i sklonost nasilnoj manipulaciji osoba izražene psihopatije postaje razumljivija, jer se u njihovim očima to javlja kao jedini način preživljavanja u hostilnom svijetu.

Sa druge strane, samo je negativan radni model sebe/anksioznost značajan i pozitivan prediktor makijavelizma, što je u suprotnosti sa klasičnim opisima ovih osoba u kojima dominira doživljaj drugih kao manje vrijednih, tj. da osoba ima pravo da manipuliše njima i iskorišćava ih. Moguće je da u osnovi makijavelizma tako- 
đe leži i doživljaj sopstvene manje vrijednosti, te stoga osoba pokušava da drugim metodama, poput manipulacije, ,spletkarenja“" itd. uspije u socijalnom okruženju, kako bi kompenzovala ovaj bazični nedostatak samopoštovanja i strah od intimnosti. Radni modeli, međutim, nisu statistički značajni prediktori narcizma, ali ovo ne mora biti rezultat nepostojanja povezanosti između ovih varijabli. Neophodno je prisjetiti se da izraženo narcisoidne osobe nemaju dobar uvid u svoje ponašanje, misli i osjećanja, odnosno teže da potiskuju sve elemente slike o sebi koji se ne uklapaju u grandiozan i suštinski ranjiv self. Ovaj faktor je mogao doći do izražaja u istraživanju ovog tipa, gdje podaci počivaju na samoiskazima ispitanika.

Narcizam se od druge dvije osobine ličnosti mračne trijade razlikuje po svojoj usmjerenosti na grandiozni self i pokušaje da se isti održi kroz manipulaciju, dok su postupci makijavelista i psihopata više usmjereni na neposrednu i materijalnu korist. Osobe sa naglašenim narcizmom čvrsto vjeruju u svoju superiornost, tj. imaju nizak stepen uvida u prirodu svoje patologije, usljed čega ne treba da nas čudi odsustvo značajnih korelacija sa radnim modelima koji se mogu sagledati samo uz makar minimum ličnog uvida i iskrenosti prema sebi, a koje su odsutne kod narcisa.

Sa druge strane, makijavelizam i psihopatija pokazuju slične obrasce korelacija i regresione koefiicijente sa osobinama ličnosti mračne trijade, što je očekivano ako uzmemo u obzir da razlika između ova dva konstrukta ne leži toliko u uvjerenjima i ciljevima, već u načinu na koji se isti pokušavaju ostvariti. Tačnije, psihopatija podrazumijeva emocionalnu labilnost i impulsivnost koji su odsutni kod makijavelizma. Činjenica da je negativni radni model sebe bio pozitivan predictor obje osobine ličnosti ukazuje na eventualno postojanje latentnog kognitivnog uvjerenja o sopstvenoj manjoj vrijednosti, koje je učvršćeno kroz iskustva hladnoće i odbacivanja (bilo implicitnog, bilo eksplicitnog) u samoj porodici. Osoba kod koje je ovo uvjerenje izraženo će strepiti od svakog otvaranja ka drugima, jer vjeruje ne samo da neće postići željeni cilj obezbjeđivanja podrške i pažnje putem otvorenog izražavanja, već da će se time razotkriti pred drugima, otvoriti sebe za potencijalne napade. Komponenta izraženog negativnog modela i drugih, ne samo sebe, koja je prisutna kod psihopatije, čini intimnost sa drugima iskustvom koje je prožeto intenzivnim strahom, jer je otvaranje drugima izjednačeno sa šansom da će nas oni ozlijediti i uništiti.

Ova uvjerenja nam pružaju i drugačiji okvir interpretacije ponašanja osoba izraženog makijavelizma ili psihopatije. Tačnije, moguće je da su njihova manipulativna ili impulsivna ponašanja rezultat očajničkog nastojanja da se obezbijedi podrška drugih, kompromis sa latentnim ili čak nesvjesnim uvjerenjima o tome da nam drugi neće pružiti ono što nam treba ako to ne „otmemo“ ili ne manipulišemo njima. Strah od istinske intimnosti i averzija prema preispitivanju sopstvene vrijednosti i iskustava odbacivanja dovodi do jačanja maladaptivnog ponašanja i pretvara se u negiranje prava i emocija drugih, što je logičan ishod ako pretpostavimo da ovakve osobe vjeruju da će se i drugi na isti način ponašati prema njima. Može se reći da je okrutan i impulsivan interpersonalni stil ponašanja zapravo kompromis između dva užasavajuća ishoda koja su uvijek prisutna, iako prikrivena, u svijesti makijavelista i psihopata - da će ostati sami, napušteni, lišeni pažnje i podrške, ili da će druge osobe 
iskoristiti istinsku intimnost $\mathrm{i}$ otvoreno ispoljenu emociju protiv njih samih kako bi ih unizili, odbacili, uništili. Jasno je da ovakav način gledanja na patologiju mračne trijade otvara i nove mogućnosti terapijskog tretmana, npr. kroz preispitivanje ovih uvjerenja, njihovo testiranje, ili redefinisanje odluka donesenih u ranom djetinjstvu.

Praktična implikacija ovog istraživanja koja se nameće jeste da je u savjetodavno-terapijskom radu sa pacijentima izraženih osobina ličnosti mračne trijade neophodno djelovati na dva fronta: 1) osvjestiti ih u pogledu toga koje ciljeve i potrebe (poput dobijanja pažnje i podrške drugih, sticanje osjećaja sigurnosti) žele da ostvare svojim ponašanjem, a za koje podsvjesno smatraju da ih ne mogu ostvariti na zdravije i društveno prihvatljivije načine, vjerovatno na osnovu iskrivljene slike intimnih odnosa i drugih iracionalnih uvjerenja, 2) podstaći ih na preispitivanje ranih iskustava u porodici koja su doprinijela formiranju ovakve slike intimnosti i drugih kognitivnih uvjerenja. Osnovna ogromnog broja terapijskih intervencija jeste da osoba kroz reminiscenciju i analizu ključnih sjećanja i situacija u svom djetinjstvu preispita zaključke koje je donijela na osnovu istih i promijeni ih ili disvalidira iz perspektive racionalne i odrasle osobe. Kroz analizu porodičnih iskustava osobe bi mogle shvatiti da je veliki dio njihovih narcisoidnih, manipulativnih i neempatičnih postupaka motivisan iskrivljenom slikom o tome kako odnosi izgledaju (npr. da je "nedozvoljeno" direktno tražiti od drugih ono što želimo) koja je formirana na osnovu ograničenog raspona selektivno i nezrelo protumačenih iskustava u djetinjstvu. $\mathrm{Na}$ taj način se kod osobe razvija svijest o slobodi i dostupnosti alternativa za drugačije, zdravije ponašanje, a staro i maladaptivno ponašanje se prestaje shvatati kao "logično" i "nužno".

Naravno, ovo istraživanje pati i od mnogobrojnih ograničenja koje upozoravaju na oprez prilikom tumačenja dobijenih rezultata i daju smjernice za buduća istraživanja. Kao što je već istaknuto, osnovna mana jeste što se o kvalitetu ranih porodičnih iskustava ispitanika zaključivalo na osnovu njihovih radnih modela porodične vezanosti u sadašnjosti, te se stoga nameće potreba da se u budućim istraživanjima više pitanja posveti ispitivanju konkretnih ranih porodičnih iskustava i svim iskustvima koja su do odraslog doba mogla promijeniti jednom formirani kvalitet rane vezanosti. Dalje, umjesto radnih modela kao prilično opštih mjera slike intimnih odnosa sa drugima i sopstvene vrijednosti $\mathrm{u}$ istima, $\mathrm{u}$ naredna istraživanja bi bilo korisno uključiti preciznije mjere kao što su rane maladaptivne kognitivne šeme, na osnovu kojih bi se daleko preciznije mogla izdvojiti disfunckionalna kognitivna uvjerenja, pristrasnosti i greške koje dovode do maladaptivnih obrazaca ponašanja osoba kod kojih su osobine ličnosti mračne trijade izražene.

\section{Literatura}

Ainsworth, M.D.S., Blehar, M.C., Waters, E., \& Wall, S.N. (2015). Patterns of Attachment: A Psychological Study of the Strange Situation (1st ed.). Psychology Press. https:// doi.org/10.4324/9780203758045 
American Psychiatric Association, DSM-5 Task Force. (2013). Diagnostic and statistical manual of mental disorders: DSM-5 ${ }^{T M}$ (5th ed.). American Psychiatric Publishing, Inc.. https://doi.org/10.1176/appi.books.9780890425596

Bowlby, J. (1982). Attachment. Attachment and loss (Vol. 1). Loss. Basic Books.

Brennan, K. A., Clark, C. L., \& Shaver, P. R. (1998). Self-report measurement of adult romantic attachment: An integrative overview. In J. A. Simpson \& W. S. Rholes (Eds.), Attachment theory and close relationships (46-76). The Guilford Press.

Brewer, G., Bennett, C., Davidson, L., Ireen, A., Phipps, A.-J., Stewart-Wilkes, D., \& Wilson, B. (2018). Dark triad traits and romantic relationship attachment, accommodation, and control. Personality and Individual Differences, 120, 202-208. https:// doi.org/10.1016/j.paid.2017.09.008

Corry, N., Merritt, R. D., Mrug, S., \&Pamp, B. (2008). The factor structure of the Narcissistic Personality Inventory. Journal of Personality Assessment, 90 (6), 593-600. https://doi.org/10.1080/00223890802388590

Dinić, B. M., Petrović, B., \& Jonason, P. K. (2018). Serbian adaptations of the Dark Triad Dirty Dozen (DTDD) and Short Dark Triad (SD3). Personality and Individual Differences, 134, 321-328. https://doi.org/10.1016/j.paid.2018.06.018

Holmes, J. (2003). Narcizam. Naklada Jesenski i Turk.

Jacoby, M. (1991). Individuation and Narcissism: The Psychology of Self in Jung and Kohut (1st ed.). Routledge. https://doi.org/10.4324/9780203753897

Jakobwitz, S., \& Egan, V. (2006). The dark triad and normal personality traits. Personality and Individual Differences, 40(2), 331-339. https://doi.org/10.1016/j. paid.2005.07.006

Jerković, I. i Zotović, M. (2010). Razvojna psihologija. Futura štampa.

Jonason, P. K., Lyons, M., \& Bethell, E. (2014). The making of Darth Vader: Parent-child care and the Dark Triad. Personality and Individual Differences, 67, 30-34. https:// doi.org/10.1016/j.paid.2013.10.006

Jones, D. N., \& Paulhus, D. L. (2009). Machiavellianism. In M. R. Leary \& R. H. Hoyle (Eds.), Handbook of individual differences in social behavior (pp. 93-108). The Guilford Press.

Jones, D. N., \& Paulhus, D. L. (2014). Introducing the Short Dark Triad (SD3): A brief measure of dark personality traits. Assessment, 21(1), 28-41. https://doi. org/10.1177/1073191113514105

Kamenov, Ž. i Jelić, M. (2003). Valifacija instrumenta za mjerenje privreženosti u različitim vrstama bliskih odnosa: modifikacija Brennanova Inventara iskustava u bliskim vezama. Suvremena psihologija, 6, 22-32.

Krumenacker, J. B. (2019). The Dark Triad of Personality: The Relation to Attachment and Observing Ego. [Doctoral dissertation, Carlow University]

Kuljić, R. (2012). Sociologija. M.B. Press.

Leary, M. R., Bednarski, R., Hammon, D., \& Duncan, T. (1997). Blowhards, snobs, and narcissists: Interpersonal reactions to excessive egotism. In R. M. Kowalski (Ed.), Aversive interpersonal behaviors (pp. 111-131). Plenum Press. https://doi. org/10.1007/978-1-4757-9354-3_6

Marić, J. (2006). Klinička psihijatrija. Grafid. 
Mikulincer, M. (1995). Attachment style and the mental representation of the self. Journal of Personality and Social Psychology, 69(6), 1203-1215. https://doi. org/10.1037/0022-3514.69.6.1203

Mrđa, P. (2017). Afektivna vezanost i mračna trijada: razlike obrazaca afektivne vezanosti u odnosu na narcizam, makijavelizam i psihopatiju. 10. Naučno - stručna konferencija "Studenti u susret nauci” sa međunarodnim učešćem, Zbornik radova (487-494), Banja Luka.

Paulhus, D. L., \& Williams, K. M. (2002). The Dark Triad of personality: Narcissism, Machiavellianism and psychopathy. Journal of Research in Personality, 36(6), 556563. https://doi.org/10.1016/S0092-6566(02)00505-6

Rauthmann, J. F. (2012). The Dark Triad and interpersonal perception: Similarities and differences in the social consequences of narcissism, Machiavellianism, and psychopathy. Social Psychological and Personality Science, 3(4), 487-496. https://doi. org/10.1177/1948550611427608

Stefanović-Stanojević, T. (2011). Afektivna vezanost: razvoj, modaliteti i procena. Filozofski fakultet.

Wai, M., \& Tiliopoulos, N. (2012). The affective and cognitive empathic nature of the dark triad of personality. Personality and Individual Differences, 52(7), 794-799. https:// doi.org/10.1016/j.paid.2012.01.008

World Health Organization. (2018). International statistical classification of diseases and related health problems (11th Revision). Retrieved from https://icd.who.int/ browse11/l-m/en

\title{
Luka Borović ${ }^{2}$
}

Department of psychology,

Faculty of Philosophy, Pale,

University of East Sarajevo,

East Sarajevo, Republic of Srpska, Bosnia and Herzegovina

\section{Jelena Marković}

Secondary school "Sveti Sava",

Loznica, Serbia

\section{INTERNAL WORKING MODELS OF AFFECTIVE ATTACHMENT AS PREDICTORS OF DARK TRIAD}

\begin{abstract}
The basic goal of this research was to examine whether internal working models of self and significant others are significant predictors of dark triad personality traits. The concept of an internal working model is the key link in attachment theory which

\footnotetext{
${ }^{2}$ luka.borovic@ffuis.edu.ba

Please cite as: Borović, L., \& Marković, J. (2021). Unutrašnji radni modeli afektivne vezanosti kao prediktori mračne trijade [Internal working models of affective attachment as predictors of dark triad]. Godišnjak za psihologiju, 18, 41-58. https://doi.org/ 10.46630/gpsi.18.2021.03
} 
connects past experiences with current patterns of behavior, maintained by dysfunctional cognitive schemas developed by generalizing aversive experiences. The dark triad consists of narcissism, psychopathy and Machiavellism. The instruments used were the Family Attachment Questionnaire by Brenan et al. (1998), and Short Dark Triad (SDT3) by Jones \& Paulhus (2014). The sample of the research consisted of $\mathrm{N}=123$ participants, age 20 to 63 , with an average age of $M=30.41, S D=9.06$. Males formed $43 \%$ of sample. Regression analyses show that model which consists of anxiety and avoidance dimensions is significant predictor of Machiavellism, $F(2,120)=6.26, p$ $=.003, R^{2}=.09$, and they predict $9 \%$ of variance, as well as psychopathy, $F(2,120)$ $=8.98, p<.000, R^{2}=.13$, where they predict $13 \%$ of variance, but not narcissism, $\mathrm{F}(2,120)=0.24, p=.79, R^{2}=.01$, in which model predicted only $1 \%$ of variance. Avoidance is statistically significant and positive predictor of psychopathy $(\beta=.29, p=$ $.003)$, and anxiety is statistically significant and positive predictor of Machiavellism ( $\beta$ $=.26, p=.004)$, as well as psyhopathy $(\beta=.22, p=.025)$. The results of study suggest that these traits are founded on an image of self as an inadequate person and the world as a hostile place, in which other persons will try to harm us if we dare to be open towards them. Manipulation and emotional insensitivity of psychopaths and Machiavelists should be interpreted as a way to reach compromise with these key beliefs and attitudes. On the other hand, narcissism did not correlate with working modes, possibly because of low levels of insight in these persons who are strongly invested in maintaining grandiose self.

Key words: affective attachment, internal working models, dark triad

Primljeno: 05.01.2021.

Primljena korekcija: 08.05.2021.

Prihvaćeno za objavljivanje: 04.06.2021. 